\title{
The Future of Retirement in Canadian Universities ${ }^{\dagger}$
}

\author{
THOMAS FLANAGAN*
}

\begin{abstract}
There is a strong movement toward legal abolition of fixed-age retirement in Canada. Quebec passed a special statute for that purpose in 1982. Human rights legislation has been interpreted to that effect in Manitoba and is tending in that direction in New Brunswick. Section 15 of the Canadian Charter of Rights and Freedoms will probably have the same result for all of Canada, once it comes into effect on April 17, 1985. This poses a novel challenge to Canadian universities, for retirement of professors at 65 is well entrenched. Several factors justify the existing practice, including the institution of tenure, the professorial pay schedule, and the need for intellectual rejuvenation. However, the arguments are unlikely to prevail against judicial interpretation of the Charter and of human rights legislation. Thus universities should now consider the ramifications. Possible measures include facilitation of early retirement, modification of pension and benefit plans, and more systematic assessment of academic staff throughout their entire careers.
\end{abstract}

\section{RÉSUMÉ}

Il existe un fort mouvement visant à abolir l'âge légal obligatoire de la retraite au Canada. Québec a présenté une loi spéciale à ce sujet en 1982. La loi des droits de la personne a été interprétée à cet effet au Manitoba et s'oriente dans cette direction au Nouveau-Brunswick. La Section 15 de la Charte canadienne des Droits et Libertës aura probablement le même résultat pour tout le Canada lorsqu'elle prendra effet le 17 avril 1985. Cela pose un nouveau défi dans les univeristés canadiennes quant à la retraite des professeurs à 65 ans. De nombreux facteurs justifient l'existence de la pratique actuelle, incluant la permanence, les échelles de salaires et le besoin d'un rajeunissement intellectuel du corps profes-

$\uparrow$ The research presented in this paper has been financially supported by the Social Sciences and Humanities Research Council of Canada.

* Political Science, University of Calgary 
soral. Cependant, ces arguments sont peu susceptibles de l'emporter sur l'interprétation judiciaire de la Charte et de la loi des droits de la personne. Ainsi, les universités devraient dès maintenant en considèrer les conséquences. Les mesures à envisager incluent la possibilitė d'une retraite prématurée, la modification des régimes de pension et d'avantages sociaux et une évaluation plus systématique du personnel académique en cours de carrière.

It has become common to speak of retirement at a predetermined age as "compulsory" or "mandatory retirement," but these terms are rather misleading (Sowell, 1980: 194). In very few cases is retirement at a certain age mandated or compelled by law. It normally rests upon freely bargained collective agreements or upon employer policy connected with a pension plan. A fixed retirement age is thus usually part of a package of terms and benefits which employers and employees have found acceptable in a particular industry. Retirement at a specified age means that the employer's obligation to employ a worker ends at that age. Properly speaking, compulsion enters the picture only when government legislates an age of retirement or forbids employers and employees to voluntarily establish one. Since the terms "mandatory" and "compulsory retirement" conceal the true location of coercion, this paper will use the term "fixed retirement."

From small beginnings at the end of the nineteenth century, fixed retirement, usually at age 65, grew to become a major social institution following World War II. Governments led the way by making 65 an age threshold for public pensions and other benefits. Public and private employers fell into line by creating their own pension schemes with payout commencing at 65 . Fixed retirement and pension plans became standard policies for large employers in Canada, including universities. Although there were always some who fought the imposed necessity of retirement, resistance was minor until the 1970's when "ageism" began to be compared to racism and sexism. The new climate of opinion has led to legal changes which threaten to make fixed retirement a thing of the past for most employers and certainly for institutions of postsecondary education in Canada. This paper addresses three dimensions of the transformation through which universities are now moving: 1) the legal changes to which universities, like other employers, are subject; 2) the special circumstances which make a stronger theoretical argument for fixed retirement of academic staff in universities than for many other professions; 3 ) the creative responses which university administrators and staff associations can make to events.

\section{Recent Legal Developments}

The rise of resistance to "age discrimination" can conveniently be dated from the passage of the Civil Rights Act of 1964 in the United States. Some sentiment was expressed at the time to include age along with race and sex as prohibited 
grounds of discrimination, but instead Congress instructed the Secretary of Labor to study the question of age. The result was the Age Discrimination in Employment Act, 1967, which prohibited discrimination in employment against those between the ages of 40 and 65 . These boundaries were put around age purposely in order to target the problem of older workers seeking employment and at the same time to exclude the issue of fixed retirement, for which 65 was by far the most common age trigger at that time.

This precedent was quickly followed in Canada. Between 1969 and 1983, the federal government and all provinces introduced the concept of age discrimination into their human rights legislation. To avoid impact on retirement practices, all provinces except Manitoba, New Brunswick and Quebec put a "cap" of 65 on their age provisions. The federal government left age undefined but accomplished the same objective by stating that fixed retirement was not a discriminatory practice if "an individual has reached the normal age of retirement for employees working in positions similar to the position of the individual." 1

Events in Manitoba broadened age discrimination to include fixed retirement. The first provincial Human Rights Act, passed in 1970, contained no reference to age. Age appeared for the first time in a wholly revised Act adopted in 1974. Although no upper boundary was put on age, there was almost certainly no intention to interfere with well established retirement practices. The issue was not even mentioned in government press releases or in the legislative debates surrounding the Act. ${ }^{2}$ Two cabinet ministers later said in public that the cabinet also had never contemplated that the Act would abolish fixed retirement (Rothstein, 1982: 78-79). The Act itself contained a rather ambiguously worded clause which may have been intended to sanction fixed retirement :

$7(2)$. No provision of section 6 or of this section relating to age prohibits the operation of any term of a bona fide retirement, superannuation, or pension plan....

The wording of this clause seems to have been inspired by a similar clause in the American ADEA which, after much controversy, was finally interpreted by the Supreme Court in 1977 as allowing fixed retirement. ${ }^{4}$

However, the establishment of "legislative intent" in British jurisprudence depends more on construction of the statutory language than on reconstruction of the motives of the legislators. Individuals faced with retirement against their will almost immediately began to bring complaints of age discrimination to the Manitoba Human Rights Commission. One such complaint led to the pathbreaking board of adjudication decision of Derksen v. Flyer in 1977 that fixed retirement violated the Human Rights Act. ${ }^{5}$ This interpretation was also streng. thened by a 1976 amendment which removed the word "retirement" from s. 7.(2), thus undercutting the argument that fixed retirement was a legal exception to the general prohibition of age discrimination. ${ }^{6}$

Derksen $v$. Flyer did not have the immediate effect of putting an end to fixed retirement in Manitoba because the Human Rights Commission, under behind- 
the-scenes pressure from the provincial government, followed an internal policy of dealing with retirement complaints only in the rare instances where there was no pension plan (MHRC, 1975, 1976, 1978). The large employers that have compulsory retirement almost always have pension arrangements. However, this tactic could not work for long. The lawyers of Aubrey Newport, a recently retired provincial civil servant, forced the Commission to take his complaint in November, 1978 , by filing for a writ of mandamus against the Commission. ${ }^{7}$ When the Commission accepted the complaint but appeared to be moving sluggishly, Imogene McIntire, a University of Manitoba professor threatened with imminent retirement, by-passed the Commission by taking her case directly into the courts. The McIntire case resulted in 1981 in a decisive verdict, affirmed on appeal that same year, that fixed retirement was incompatible with the Human Rights Act even though it had been accepted in collective bargaining between the University and the Faculty Association. ${ }^{8}$ In quick succession, a series of related cases extended the principle to virtually all situations in the public and private sectors. ${ }^{9}$ All had to bow to the Human Rights Act. The only point left to be determined is whether a provincial statute adopted subsequent to the Human Rights Act and allowing school boards to retire teachers at 65 is valid by virtue of this later passage. ${ }^{10}$

Since 1973, New Brunswick has had an uncapped provision against age discrimination in its Human Rights Act, but it also has had an exemption for "the terms or conditions of any bona fide retirement or pension plan. ${ }^{11}$ Until recently, that province's Human Rights Commission did not take retirement complaints unless there was no pension plan, which effectively exempted most large employers (Croll, 1979: 144).

However, the New Brunswick Human Rights Commission is now attempting to revise its practices. In 1981, the Commission took the complaint of Dr. Geza Kuun, a University of New Brunswick professor who did not wish to retire at the normal age of 65 . Under pressure from the Commission, the University offered Dr. Kuun two more years of employment, on the explicit condition that he then retire. Dr. Kuun signed an agreement, worked two more years, then approached the Commission in 1983 with a new complaint. The tribunal established to hear the case ruled that a collective agreement involving fixed retirement does not violate the New Brunswick Human Rights Act, and that in any event Dr. Kuun, in accepting a settlement of his earlier complaint, was estopped from complaining again in the same matter. ${ }^{12}$ The Commission has appealed the Kuun case and is hoping to receive similar complaints not involving the inconvenient fact of a prior settlement. ${ }^{13}$

Alone among Canadian jurisdictions, Quebec has prohibited fixed retirement through unambiguous, special-purpose legislation. ${ }^{14}$ Effective October 1, 1983, it also added the phrase "age except as provided by law" to its list of prohibited criteria of discrimination. ${ }^{15}$ Elsewhere in Canada, commissions of inquiry have from time to time recommended the legislative abolition of fixed retirement, but no other provincial government has pushed ahead (Herzog, 1980; Walton, 1980). 


\section{The Canadian Charter of Rights and Freedoms}

Developments at the federal level have been more dramatic. In 1979, the Senate Special Committee on Retirement Age Policies (Croll Committee) recommended the "progressive abolition" of fixed retirement, raising the age one year at a time for five years, at which point it would be eliminated altogether (Croll, 1979: 39). This idea was not acted upon directly, but an even more radical approach was incorporated into section 15(1) of the Canadian Charter of Rights and Freedoms, which comes into effect April 17, 1985. This section reads:

15.(1) Every individual is equal before and under the law and has the right to the equal protection and equal benefit of the law without discrimination and, in particular, without discrimination based on race, national or ethnic origin, colour, religion, sex, age or mental or physical disability. ${ }^{16}$

Since the term "age" is not bounded in the Act, and since there is no saving clause referring to retirement plans, one may infer an impact on fixed retirement. Indeed, the federal Minister of Health and.Welfare has stated that s.15(1) was intended to put an end to fixed retirement (Rothstein, 1982: 70). However, a number of legal questions will have to be resolved before fixed retirement in universities is finally abolished.

First is the jurisdictional issue. According to s.32(1)(b), the Charter applies "to the legislature and government of each province in respect of all matters within the authority of the legislature of each province." This probably renders ultra vires the legislation in Alberta which has established a fixed retirement age for professors. ${ }^{17}$ But generally in Canada retirement for professors rests upon provisions of unlegislated collective agreements. Is a university part of the "government" of the province within the sense of the Charter? The answer seems likely to be yes. Provincial governments incorporate universities under statute, appoint their boards of governors, approve their degree-granting programmes, and pay $90 \%$ of their costs: The status of universities will be decided in the context of parallel litigation challenging fixed retirement in hospitals, public schools, and similar provincially funded institutions.

Second, universities may attempt to exempt themselves by appealing to section 1 of the Charter:

1. The Canadian Charter of Rights and Freedoms guarantees the rights and freedoms set out in it subject only to such reasonable limits prescribed by law as can be demonstrably justified in a free and democratic society.

This clause is terra incognita, and it is not easy to predict what the courts may do with it (Whyte, 1982). However, the word "demonstrably" means that the onus will be on a university to prove that its operations will be gravely impaired by the absence of fixed retirement. The closest analogy in existing human rights law is the "bona fide occupational qualification" (bfoq) recognized in most such legislation. Age discrimination, including fixed retirement, has been successfully defended in cases where public safety would be seriously jeopardized by faulty 
performance and where, in the absence of a more exact mechanism of assessment, age may be the best available proxy for predicting the likelihood of impairment. But the Supreme Court of Canada has said that a bfoq exemption from the general prohibition of age discrimination is not justified "where concern for the employee's capacity is largely economic, that is where the employer's concern is one of productivity...."18 That is, an employer may not retire workers past a certain age merely because they are on average less productive or less innovative. Some overriding public interest must be demonstrated. For example fixed retirement for judges might be defended as a way of preserving their political neutrality by protecting them from dismissal for cause, which might be more likely if governments could not count on their certain retirement (Rothstein, 1982: 304). It seems unlikely that universities will be able to muster arguments of comparable urgency.

Third, universities may be able to persuade their provincial governments to invoke the nonobstante provisions of s. 33 of the Charter:

33(1). Parliament or the legislature of a province may expressly declare in an Act of Parliament or of the legislature, as the case may be, that the Act or a provision thereof shall operate notwithstanding a provision included in section 2 or sections 7 to 15 of this Charter.

When the Charter was adopted, it was widely believed that the provinces, fearing the political consequences of a legislative override of "human rights," would hardly ever make use of s.33. In fact, Quebec has used it wholesale as an expression of contempt for constitutional amendments adopted against the wishes of the provincial government, and Alberta has announced it will use it to maintain its ban on strikes by provincial employees, should the courts decide this ban violates the "freedom of association" guaranteed by s.2(d) of the Charter. Only time will tell whether any province will risk an override on the less than crucial issue of fixed retirement. It is hard to believe that a provincial government would act only for the sake of universities, but one or more might do so to retain its retirement policies for the entire provincial public service. In such a case, universities might be carried along. However, the override is unlikely to be a lasting prop of fixed retirement since it must be renewed by the provincial legislature every five years. Sooner or later, it will come up for renewal when a different party, pledged to undo the work of the previous government, controls the legislature.

The most plausible conjecture is that existing university retirement schemes will be widely challenged in litigation immediately after April 17, 1985. The complainants will probably win in court. Some islands of fixed retirement may survive through resort to s.33, but these will probably be few and will always be susceptible to repeal on short notice.

\section{Retirement and the University}

Fixed retirement has never been an issue for the self-employed and for those employed by small businesses. In such circumstances, those who work can readily 
make individual decisions in close consultation with colleagues and employers. Fixed retirement has evolved as a way of solving the personnel problems of large organizations. In that setting, it must be presumed to have some utility, because a very large majority of such employers, both public and private, establish a retirement age along with a pension plan. Employers cling to these arrangements and have tried to defend them against government intervention (Howard, Peavy, \& Selden, 1982: 238).

Large employers see several advantages in a fixed retirement age. It spares them the expense and acrimony of documenting a dismissal for cause for older employees whose productivity may be declining. It allows them to design salary ladder systems knowing that retirement prevents increases from going on indefinitely. And it enables them to advance the careers of younger men with some predictability, because they know when senior positions will be vacated. To procure these advantages, they are willing to sacrifice the positive contribution that might be made by some employees willing and able to work past normal retirement age. Even this loss is often avoided by provisions in the retirement plan for discretionary extensions or re-hiring.

Against these gains to the employer the greatest argument is that fixed retirement is a form of discrimination based on age and therefore out of place in a society committed to equal opportunity for all regardless of accidental or irrelevant personal characteristics. There is some difficulty with this argument since age is not an immutable characteristic like race or sex but rather a part of the life cycle through which all human beings pass. Just as we have special arrangements for children, it may not be unfair or irrational to have special arrangements for those past a certain age, if the connection between that age and relevant employment characteristics is so strong that age becomes a reliable indicator of performance. But that crucial link is in fact rather weak. Systematic research as well as common observation suggests a wide variation in the rate of mental and physical, as compared with chronological, aging.

Another way of stating the personal choice argument is that fixed retirement is a significant reduction in freedom for those affected by it. Even if the majority wishes to retire by that age anyway, a substantial minority is prevented from continuing. This seems a regrettable anomaly in a liberal society which tries to promote individual choice.

At this abstract level, the argument seems impossible to resolve. How do you balance economic advantage against the value of human rights and individual choice? However, the problems come into clearer focus when we consider that organizations, like individuals, are highly variable in their requirements. There is scarcely any problem of fixed retirement among the blue collar work force of manufacturing industries because hardly anyone wants to continue hard, grinding, assembly-line work past 65 . Military and quasi-military organizations like police forces have special problems because of their hierarchical structure and extensive differentiation of ranks. Promotion through the junior ranks depends upon the predictable retirement of senior officers. Different problems again rise when public safety is an issue. When hundreds of lives may be at stake, we want to 
ensure that drivers and pilots are in top mental and physical condition. Thus arises the bfoq justification for fixed retirement.

These reflections on the diversity of organizations suggest that the singleminded demand that no one be required to retire at a specific age may be as inappropriate as universal fixed retirement. This leads to consideration of the unique situation of universities and their academic staff.

The first special factor is the commitment to academic freedom embodied in the institution of tenure. In legal terms, academic tenure resembles job security provisions found in many contracts of employment (after a probationary period, dismissal may ensue only if the employer shows cause); but it is hedged around with such strong social and psychological supports that dismissal for cause rarely happens in Canadian universities. Mandatory retirement may be considered a reasonable concession by academic staff in return for such security of employment. Without retirement at a fixed age, academic tenure would be tantamount to a lifetime guarantee of employment, unless universities resorted to dismissal for cause more frequently. But frequent dismissal proceedings might well jeopardize academic freedom, the protection of which is the prime function of tenure. The argument is very similar to that which justifies fixed retirement for judges as a support of their political neutrality. It is safer not to put the employer in the habit of launching dismissal proceedings.

A second point is the remuneration schedule of North American professors. The rewards of being a professor can be considerable, but they are deferred. From a low starting level, salary increases indefinitely, at least for the more productive researchers. This means that peak earning power is generally achieved immediately before retirement. In most professions, older employees earn more than younger, but the difference is especially marked in the professoriate. This corresponds to the fact that academic work, particularly research, is a virtuoso performance comparable to that of athletes, artists, or entertainers. A salary structure which encourages and rewards the desired performance is a logical feature of university life. The university can afford to pay high salaries to the most renowned members of faculty in the knowledge that the burden will not continue indefinitely. These ultimate rewards are one inducement for capable young scholars to enter university teaching as compared to, say, school teaching, where the pay-off comes much quicker but also reaches an earlier plateau. An end to fixed retirement may upset the implicit bargain on which these arrangements rest.

A third point is the unusual need of universities for rejuvenation. This follows from the progressive character of modern science and scholarship. If the professoriate did not discover new knowledge but only passed on the traditional learning of the past, older staff might almost automatically be better staff. But in a dynamic scientific community, new generations of scientists and scholars embody recent discoveries in knowledge and methodology. Older researchers will undoubtedly read about the latest advances, but they are unlikely to adopt them as 
enthusiastically as the new generation learning them in graduate school. Fixed retirement seems to be a reasonable way of ensuring the necessary circulation of personnel.

Finally, it is often asserted that the abolition of fixed retirement will have little practical effect on universities or other employers because relatively few employees wish to work past 65. A Conference Board of Canada study in 1979, using a rather simplistic methodology, estimated that only about 12,000 individuals a year in Canada are at present being retired against their will (Dunlop, 1979: xiii). However, these aggregate statistics and predictions may not apply very well to the professoriate. Most academic work is not physically debilitating; rather it is often intensely interesting to those who do it. There are also important social rewards in teaching and in being part of the community of scholars. All these factors suggest that professors may be much less eager for retirement than are workers in many other occupations.

Early data from the University of Manitoba give some indication of what may happen. Of 69 academic staff who retired from 1978 through 1983, 21 (30.4\%) chose early retirement, $36(52.2 \%)$ left at the "normal" age of 65 , and 12 (17.4\%) elected to work past $65 .{ }^{19}$ Using slightly different definitions, 16 of 1138 full-time academic staff, or $1.4 \%$, were 66 or older in February, 1984. These figures are not large, but the main judicial decisions about fixed retirement occurred as recently as $1981-82$, and one case is still to be decided by the Supreme Court of Canada. As the idea of working past 65 becomes more familiar, it seems likely that a significant minority of professors will choose that option. Precise estimates would be foolhardy since retirement decisions are powerfully influenced by many extraneous factors such as adequacy of social security and private pensions, the expected rate of inflation, and common perceptions of what is normal. Under present Canadian tax law, not many professors would continue full-time employment past 70 , for tax-exempt benefits may not accrue past 71 (Croll, 1979: 29). However, this barrier may well fall after 1985, since s. 15 of the Charter will bring such age-triggered tax rules under attack.

These reasons suggest that, even if fixed retirement is not absolutely necessary for universities, it is integrally related to a number of existing practices. When ADEA was passed in 1978, American universities lobbied Congress vigorously enough to win a temporary exemption; although ADEA raised the general age of retirement to 70 , universities were allowed to continue to retire tenured academic staff at 65 . This exemption, opposed at the time by the American Association of University Professors (AAUP), expired July 1, 1982, and was not renewed, so that universities now share the new norm of 70 . Interestingly, the prestigious "Committee A" of AAUP has opposed recent proposals to "uncap" ADEA and thus abolish compulsory retirement altogether (AAUP, 1982). For reasons like the ones given above, the AAUP continues its original stance, voiced in its 1940 Statement of Principles on Academic Freedom and Tenure, of accepting fixed retirement in principle. 
In contrast, the Canadian Association of University Teachers now favours legal abolition of a fixed retirement age coupled with maintenance of 65 as a "normal" age for retirement.

CAUT in its submission to the Special Senate Committee on Retirement recommended that compulsory retirement solely because of age should be abolished and that employees should be free to choose when they will retire subject, of course, to their continued ability to do their job. However, CAUT believes that the "normal" retirement age should continue to be 65 and that pension plans should be designed to provide a "full" pension at that age for employees who have been members of a plan for most of their normal working life (CAUT, 1983).

This position was developed by CAUT in 1979 as part of its submission to the Croll Committee (CAUT, 1979).

The issues discussed above apply to universities in general. However, the retirement question is made even more vexing by a peculiar conjunction of circumstances prevailing in the 1980 's. Universities everywhere in Canada are under intense financial pressure as part of governmental attempts to control the cost of public services. University operating budgets are at best static, and more often declining, in real value. As always in a dynamic economy, student interest continues to shift from one field to another in unforeseeable ways. The institution of tenure prevents internal reallocation of resources through dismissal of faculty in declining areas. In this situation, retirements are inevitably prized by university administrators as a way of simultaneously replacing an expensive employee by a cheaper one (replacement hiring at the junior level) and reallocating resources (transfer of positions from one department to another). Canadian universities expanded so rapidly in the late 1960's and early 1970's that the age structure of their teaching faculty is heavily weighted toward younger middle age. Statistics Canada compiled the following aggregate distribution by age of teaching faculty in 1982-83, excluding Quebec (University of Calgary, 1984):

\section{TABLE I}

Age Distribution of Teaching Faculty, 1982-83

\section{Age}

under 31

$31-35$

$36-40$

$41-45$

$46-50$

$51-55$

$56-60$

over 60
Percent of Staff

4.5

11.7

20.2

20.9

16.3

12.5

8.9

5.0 
In the next five years, according to these figures, about 1 percent of faculty will reach 65 each year - say 10 professors annually in a medium-size university of 1000 faculty members. In actual fact, the number of vacancies to fill will be somewhat higher, because a few will die or become disabled, and others will choose early retirement. However, the numbers are low enough to raise concern among those who must balance budgets while simultaneously redirecting the university's efforts towards fields of emerging student interest. The dilemma is even more acute for the new universities which, beginning from nothing, hired so many young faculty members in the last two decades. For example, The University of Calgary, with about 1100 full-time positions, projects only 47 retirements in the five years from 1984 through 1988. (University of Calgary, 1984).

The other side of this problem is the lack of opportunities for young scholars now emerging from graduate schools, a situation so familiar that it has become common to speak of an academic "lost generation." Canada's expansion of universities has created graduate programmes which stand on a world level of excellence in many disciplines. Ironically, the best-trained generation of scholars in Canadian history faces a dreary round of sessional and limited-term appointments as its members scramble for the few positions available. Their prospects may become even dimmer after 1985 if a considerable fraction of those who would otherwise have retired by 65 now choose to prolong their employment.

\section{Recommendations for Universities}

The previous section has established that there are good reasons for the existence of fixed retirement in universities. Indeed, it seems unlikely that abolition of fixed retirement in universities would be legislated in many jurisdictions if the merits of the issue could be openly debated. One may differ as to whether the best age is 65 or 70 or something in between, but the principle that there ought to be a maximum age seems defensible in the context of university life. Nonetheless, universities are faced with abolition of their existing retirement rules as a consequence of broadly drafted "human rights" legislation. It would be wise, therefore, for universities, both administrative officers and faculty associations, to ponder their responses. Below are set forth some ideas which may be worth consideration.

First, legal abolition of mandatory retirement is practically a fait accompli. The courts are very unlikely to interpret $\mathrm{s.15}$ of the Charter so as to save the practice for public employers or to sanction an exception for universities. Resort to legislative override may be possible in some provinces but will always be insecure because of the necessity for re-enactment every five years. University administrations may wish to test $\mathrm{s} .15$ in the courts or to lobby their provincial government; but if they do, they should realize their chances of success are not great. It would be wise to avoid extreme or inflammatory public statements which may alienate faculty or detract from the university's prestige by making it seem to be "against human rights." 
Instead of fighting abolition outright, universities should perhaps save their legal and political energies for the battles over pensions and benefits which are bound to ensue. Most existing human rights legislation contains clauses exempting pension plans and/or insurance policies from the general prohibition of age discrimination; ${ }^{20}$ but no such provision has been included in the Charter of Rights and Freedoms. No one can foresee at present the extent to which concessions to actuarial necessity may reappear as exemptions under s. 1 of the Charter (". . reasonable limits prescribed by law..."), as legislation based on the nonobstante clause, or even as a future constitutional amendment to the Charter. While only skimming the surface of a complex subject, we can indicate two problems which will have to be considered:

1) Pension plans currently use age triggers in a variety of ways. Two of the most common are that full benefits become available at a certain age, usually 65 , and that early retirement becomes possible at a certain age, often 55. According to the same judicial logic which will construe mandatory retirement by public employers to be prohibited age discrimination, all such age triggers will be equally suspect. If a professor wants to retire early, why should he have to wait until 55 , and why should he have to pay an actuarial penalty?

A related question is what will happen to those who work past 65 . Will they continue to make contributions matched by the employer, or will contributions cease? An arbitrary age threshold will no longer be acceptable. If university pension plans are held to be part of the public sector, they will have to be rewritten to remove all age triggers. Numerous controversies are bound to arise in the process.

2) Universities commonly provide to academic staff a number of group insurance benefits, including life insurance, short and long-term disability benefits, dental and supplementary medical coverage. Typically, the university acts as an intermediary between its faculty members and a private insurer, while also subsidizing the premiums to some degree. It will have to be determined in court whether such university programs are part of "government" in the sense of s.32 of the Charter and therefore incur the prohibition of age discrimination explicit in s.15. If so, universities may have to divorce themselves from such programmes and let faculty associations contract directly with insurers, as unions sometimes do in the private sector, or else insurers will have to devise age-neutral ways of distributing actuarial risk. The challenge will be greatest for life insurance because risk of death rises so sharply past 65 . If those who work past 65 are held to have a right to continue in the group life insurance plan, and if substantial numbers of employees do in fact postpone retirement, the plan could be severely burdened. A similar actuarial problem will exist for disability benefits.

Most of the pension and benefit problems will be technical in nature and will be solved by the ingenuity of actuaries and plan administrators (Walker \& Lazer, 1978). The university's long-term interest will be to ensure that adequate coverage is continued without creating artificial incentives for staff to continue employ- 
ment indefinitely (e.g. if an employee could indefinitely carry very large amounts of life insurance at a highly subsidized rate).

Beyond the redesign of pension and benefit plans, there are some positive things that a university can do to ensure that personal choice retirement does not become detrimental to the institution. One step is to make early retirement as financially attractive as possible. This can be achieved by easing eligibility criteria, by removing actuarial penalties, and by offering lump-sum payments or annuities to help bridge a financial gap which may exist until the retiree is eligible for Canada Pension Plan benefits. However, caution must be exercised in this approach. Making early retirement universally available on favourable terms may entice some of the university's most talented staff to "retire" early in order to start another career or even to go to work for another university. From the standpoint of university administration, selective early retirement would be the ideal procedure, used to induce the early departure of the least productive staff. However, if early retirement becomes more common, faculty associations will surely wish to include it in their list of negotiated contract provisions, so administrative flexibility may tend to decline over time.

Financial security is a major, but not the only factor in the retirement decision. Professors fear the loss of their academic identity: office and laboratory space, research support, relations with students and colleagues. Universities may be able to ease these fears, as well as make use of valuable expertise, by developing new kinds of relationships with retirees. ${ }^{21}$ Some may wish to be rehired on parttime contracts to perform selected duties in teaching, research, or administration. Others may be content if they are ensured suitable office space and access to laboratories, libraries, or computers.

On the negative side, universities will have to ensure that their performance appraisal systems are effective. One of the commonest propositions in the literature is that older employees are sometimes allowed to coast in their final years, since the employer knows they will leave at 65 (Gunderson \& Pesando, 1980: 356-357). If that departure is no longer guaranteed, it is necessary for performance appraisals to be honest and realistic as long as employment continues. Again, the literature suggests that, given the prospect of financial security, employees will makè realistic decisions about retirement if they are given realistic appraisals of their performance (Wallfesh, 1978: 36-37).

The net effect of the end of mandatory retirement will probably be an increase in costs: The increase will be apparent in higher salary costs if continuation past 65 for substantial periods of time becomes frequent. But there will be a less visible increase even if the empirical pattern of retirements is not much different from today's. What is now an automatic, predictable event will become a unique, negotiated occurrence. All retirements will become in effect early retirements, requiring an individualized package of pension benefits, lump-sum payment or annuities, and post-retirement concessions such as part-time rehiring. The aggregate benefits will be costly to negotiate and costly to provide. Insurance-type 
benefits may also become more expensive if insurers are forced to discontinue use of convenient proxies like age. In the very long run, these costs will be transferred to the professoriate, as a new salary structure will emerge to take account of the new advantages associated with the retirement decision. In the short run, the costs will have to be borne by universities, either through increased tuition fees or government grants, or through reduction of expenses in areas other than salaries for tenured faculty. In the real world, everything has a cost to be paid, even if human rights legislation often seems to presuppose that "equality of opportunity" is a costless manna from heaven.

However, the increased costs may be offset by opportunities for increased academic quality. Fixed retirement was an expeditious compromise which allowed some unproductive employees to work longer than desirable while forcing others to retire while they still had a contribution to make. It thus entailed deadweight losses in staff efficiency, even if it offered considerable savings in personnel management. Abolition of fixed retirement will open a new era in university affairs marked by more individualized treatment of faculty members. Both teaching and research will be improved if universities can find ways to help their faculty members make optimal choices about the duration of their employment and the precise form it takes in later years.

\section{REFERENCES}

American Association of University Professors. Uncapping the Mandatory Retirement Age: A Report of Committee A. Academe, 1982, 68 (5), 14a-18a.

Canadian Association of University Teachers. Brief Presented to the Special Senate Committee on Retirement Age Policies. Ottawa: February, 1979.

Canadian Association of University Teachers. Brief to the Parliamentary Task Force on Pension Reform. Ottawa: May, 1983.

Croll, D. Retirement without Tears: The Report of the Special Senate Committee on Retirement Age Policies. Hull, Quebec: Minister of Supply and Services Canada, 1979.

Dunlop, D.P. Mandatory Retirement Policy: A Human Rights Dilemma. Ottawa: Conference Board in Canada, 1979.

Gunderson, M, \& Pesando, J.E. Eliminating Mandatory Retirement: Economics and Human Rights. Canadian Public Policy, 1980, 6, (2), 352-360.

Herzog, J.P. Mandatory Retirement in British Columbia: A Review of Issues, Practices and Attitudes: Vancouver: British Columbia Human Rights Commission, April, 1980.

Howard, E., Peavy, N., \& Selden, L. Age Discrimination and Mandatory Retirement. In Morrison, Malcolm. Economics of Aging: The Future of Retirement. New York: Van Nostrand Reinhold, 1982, 217-246.

Macdonald, R.M. Mandatory Retirement and the Law. Washington, D.C. American Enterprise Institute, 1978.

Manitoba Human Rights Commission, Annual Report. Winnipeg: 1975, 1976, 1978.

Rothstein, M.E. Report of the Commission on Compulsory Retirement. Winnipeg: February, 1982.

Sowell, T. Knowledge and Decisions. New York: Basic Books, 1980. 
University of Calgary. Report of the Position Allocation Committee. January 21, 1984.

Walker, J.W., \& Lazer, H.L. The End of Mandatory Retirement: Implications for Management. New York: John Wiley and Sons, 1978.

Wallfesh, H.M. The Effects of Extending the Mandatory Retirement Age. New York: American Management Association, 1978.

Walton, F.T. Freedom in New Brunswick: The Rights to Retire, to Work, and to Earn and Receive Pensions - Report of the Industrial Inquiry Commission on Retirement Age Policy. Fredericton, N.B.: August, 1980.

Whyte, J.D. The Effect of the Charter of Rights on Non-Criminal Law and Administration. Canadian Human Rights Reporter, 1982, 3, C 82-9 to 82-10.

\section{NOTES}

1. Canadian Human Rights Act, S.C. 1976-77, c.33, s.14(c). Section 14 also contains several other less sweeping grounds on which fixed retirement may be justified.

2. See Manitoba Government News Service, press release June 7, 1974, in the Library of the Manitoba Human Rights Commission. The Attorney-General, Howard Pawley, mentioned age when he introduced the Act in to the Legislative Assembly, but only in the context of employment of older workers. Retirement was never mentioned. See Legislative Assembly of Manitoba, Debates and Proceedings, June 1, 1974, pp. 4212.4213.

3. The Human Rights Act, S.M. 1974, c.65, s.7(2).

4. United Airlines v. McMann 434 U.S. 192 (1977).

5. Peter Derksen.v. Flyer Industries Ltd., 1977, unreported; copy in Manitoba Human Rights Commission Library.

6. An act to amend the Human Rights Act, S.M., 1976, c. 48, s.7(2).

7. Interview with Jack R. London, Dean of Law School, University of Manitoba, December 14, 1983.

8. Imogene McIntire and The University of Manitoba, 2 C.H.R.R. (1981), d/310

9. The leading Manitoba decisions and the issues raised are as follows (only final decisions are cited); Manitoba H.R.C. and John N. Finlayson v. City of Winnipeg et al, 4 C.H.R.R. (1983), D/1255 (bfoq); Douglas Paterson v. E.H. Price Ltd., 3 C.H.R.R. (1982), D/904 (private sector employer); Dwight Parkinson v. Health Sciences Centre, 3 C.H.R.R. (1982), D/724 (public sector employer); Government of Manitoba v. Aubrey Newport, 3 C.H.R.R. (1982), D/721 (statutory retirement age); Bedrich v. City of Winnipeg (1981), unreported (city by-laws) Thexton v. University of Manitoba, 2 C.H.R.R. (1981), $\mathrm{D} / 318$ (collective agreement; non-academic employee of university).

10. Craton v. Winnipeg School Division No. 1 et al. 21 Man. R (2) 315, on appeal to the Supreme Court of Canada.

11. Human Rights Code, S.N.B., 1971, c.8, s.3(2)

12. Geza Charles Kuun v. University of New Brunswick (1983), unreported.

13. Observation of New Brunswick Human Rights Commission Meeting, March 6, 1984.

14. Loi sur l'abolition de la retraite obligatoire, L.Q., 1982, c. 12 .

15. Charter of Human Rights and Freedoms, R.S.Q., 1977, c.C-12. s.10, as amended 1982, c. 61, s. 3 .

16. Constitution Act, 1981, s. 15(1).

17. Universities Academic Pension Act, S.A., 1978, c. 36, 1 (g) and 9. 
18. Ontario H.R.C. and Bruce Dunlop and Harold E. Hall and Vincent Gray v. The Borough of Etobicoke, 3 C.H.R.R. (1982), D/781, at D/783.

19. Letter to the author from Dr. S.L. Bond, Associate Vice-President, University of Manitoba, January 30, 1984.

20. Canadian Human Rights Act, s.14(d); British Columbia Human Rights Code, s. 8(3); Saskatchewan Human Rights Code, s.16(4); Manitoba Human Rights Act, s.7(2); Ontario Human Rights Code, s.21, 24(2), 24(3); New Brunswick Human Rights Act, s. 3(6); Nova Scotia Human Rights Act, s.11 B(3); Prince Edward Island Human Rights Act, s. 11; Newfoundland Human Rights Act, s.9(5).

21. The University of Manitoba is now considering a "senior scholar" plan to provide retirees with access to facilities. Interview with Dr. Sheryl Bond, Associate VicePresident, December 14, 1983.

\section{This Publication is available in Microform.}

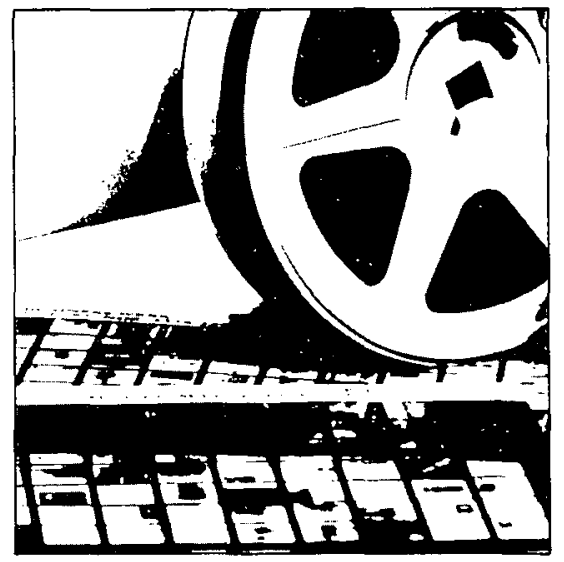

University

Microfilms

International

Please send additional information

for

Name

(narme in nutblicuticin

Institution

Street

City

State Zip

300 North Zeeb Road Dept. P.R

Ann Arbor. Mi. 48106 